\title{
OBITUARY OF JAMES DUFFY
}

Written by Deborah Pellow
Syracuse University

James Duffy, ASA Executive Secretary 1967 to 1980 , died from cerebral hemornage at dawn on Thanksgiving Day, November 25, 1999.

Duffy, as so many of us called him, taught at Brandeis University for 42 years. He enjoyed an unusual and distinctive academic career. At Brandeis, he was formally affiliated with the Department of Romance Languages, but he also taught and advised doctoral students in history, comparative literature, African, Afro-American, and Latin American studies. He also served the University as acting chairman of the Department of Philosophy.

Outside the university, he was best known for his Africana research and writing. He worked in the field of Portuguese colonial history. As colleagues have noted, his literary style was that of a humanist, and he contributed much to the world of scholarship: Shipwreck and Empire: Being an Account of Portuguese Maritime Disasters in a Century of Decline (Harvard University Press, 1955), Portuguese Africa (Oxford University Press, 1959), Portugal in Africa (Oxford, 1962) and with Robert Manners the edited volume Africa Speaks (Van Nostrand, 1961) and A Question of Slavery (Harvard University Press, 1967). In recent months, Jane Kramer, staff writer for The New Yorker recalled her work in Lisbon in 1975 covering the revolution, she spoke of Duffy's Portuguese Africa as the definitive history of the region.

I got to know and like Duffy shortly after he became executive secretary of the ASA and fell in love with my good friend and his coworker Paula Barker, who subsequently became his wife. Some have said that Duffy took a moribund organization, led it through difficult times (following the 1969 Montreal meeting) and converted it to a more professional one. He founded Crossroads Press, the Association's publishing arm, and actively supported the creation of Issue, $A$ Joumal of Opinion. As Peter Gutkind wrote for Duffy's memorial service in late December, Jim Duffy "radiated a kaleidoscope of personality, emotions, intellect, reason, enigma and paradox. Irony and cynicism featured prominently in conversation. He sometimes seemed slightly quirky - even eccentric - but far more often compassionate, indeed sentimental."

To friends and loved ones, he was nurturing in the extreme. Whether I needed advice, a shoulder to cry on or a meal, (he was a great cook), he was there for me. Because he could seem gruff, because he was determined to get it done and to get it done right (even licking the stamps himself for ASA mailings to be sure they got out on time), he rubbed some people the wrong way. Others, perhaps envious of Duffy's abilities - whether running an office, writing a book, or succeeding in love - provoked his untimely departure from the ASA, an organization to which he was extraordinarily dedicated and which he ran with style.

In 1985, nine years before retiring from Brandeis and already into his sixth decade of life, Duffy began a new "career": he published his first novel for young adult readers, The Revolt of the Teddy Bears: A May Gray Mystery. This began what became an impressive series of books, thirteen in all, some published under his own name, some under the pen name Pieter van Raven. Each had a clear moral center, each dealt with a hard issue, whether politics, racism, the exploitation of workers, women's suffrage, the disappearance of a child. In 1990, he received the Scott O'Dell Awards for Historical Fiction for his novel A Time of Troubles. The Scott O'Dell Awards was established to honor a distinguished work of historical fiction for children or young adults.

Duffy is survived by his wife, Paula Barker Duffy, who is leaving The Free Press, where she is publisher, to head the University of Chicago Press on August 1, 2000; his son, David of New York City, and four daughters: Amanda Duffy Cedrone and Priscilla, both of Milton, MA, Sarah of San Francisco, and Anna, a student at Carleton College.

\section{APPROVED MIINUTES}

AFRICAN STUDIES ASSOCIATION BOARD OF DIRECTORS MEETING AND BUSINESS MEETING

FALL 1999, PHILADELPHIA

Wednesday, November 10, 1999. Board Meeting.

Present: Omofalabo Ajayi-Soyinka, Judith Byfield, Mark Delancey, Kenneth Harrow, Beverly Hawk, Dorothy Hodgson, Frank Holmquist, Eileen Julien, Stephen Ndegwa, Richard Roberts, David Wiley

Recording: Loree D. Jones

Call to Order. President David Wiley called the meeting to order.

INTRODUCTIONS. There was a General Discussion of Board schedule and agenda items. A discussion of the draft of "Guidelines for Ethical Conduct of Research on Africa" was added to the agenda of the Board meeting on Thursday, November 11, 1999. The Board discussed the impromptu Board panel on the "Wonders of the African World Series." An effort would be made to invite Henry Louis Gates to participate or to send a representative in his place. Several Board members volunteered to serve on the panel.

Approval of Minutes. The minutes of the Spring 1999 Board meeting were discussed and were not approved. Greene offered a revision of part of the minutes. The chairs of standing committees were asked to rewrite sections of the minutes related to their committees. The minutes would be approved via email before the Spring 2000 meeting. The Board instituted a new policy of approving minutes between meetings. President's Report and Discussion. President Wiley reported on the direction of the Association. Wiley noted that the Association was moving in a positive direction. This move is evidenced by the commitment and diligence of the Board of Directors, the professionalism of the new Executive Director and Executive Office, and the apparent success of the 1999 Annual Meeting.

Wiley reported that the Association's finances had been negatively affected by personnel issues and noted that a successful conference could contribute to the financial health of the Association. As the Annual Meeting is a major source of funding for the Association, Wiley asked the Board to work to ensure high registration numbers for the Nashville meeting in 2000.

Wiley noted that several new projects indicate the Association's desire to take a more activist stance. These projects include the Claude Ake Prize program, the ASA-MSU Electronic Publishing Project, and the African Studies Survey project developed by Larry Bowman.

Wiley suggested that the Association seek funding to build membership, develop outreach programs and expand the International Visitors Program.

Treasurer's Report-Mark Delancey. Mark Delancey suggested that the Association spend conservatively given its current financial state. He reported that he and Frank Holmquist, chair of the Finance Committee, researched the Association's investment portfolio. Delancey sent the Association's investment portfolio to other investment companies for review. The returns fit with the Association's guidelines, which were conservative. If the Association allowed for more flexibility and less conservative investing the returns may increase. Delancey noted that, while the general belief is that the Association's profits should be higher given the current investment climate, in fact the stock of only a few companies is rising. Delancey suggested that the Board redefine its guidelines including the idea of only investing in "socially responsible" companies; evaluate the fees being charged by investor; and consider investing with an established retirement fund. Delancey suggested that the Finance Committee and the Executive Director bring suggestions to the Spring Board meeting about investment options.

Executive Director's Report- Loree D. Jones. On June 14, 1999, I began my tenure as Executive Director of the African Studies Association. I appreciate the confidence in me you have demonstrated by hiring me. I am honored to work with you to further the missions and goals of the Association.

Rutgers UNIVERSITY. Part of the charge given to me by the Board of Directors is to develop 